\title{
A study of oropharyngeal parasites infection in doves and domestic pigeons in some villages of Garmian -Iraqi Kurdistan region
}

\author{
Mohammed Abdulkareem Wahhab \\ Sulaimani Polytechnic University Sulaimani, \\ Iraq mohammed.wahhab@spu.edu.iq
}

\author{
Nawzad Rasheed Abdulrahman \\ College of Veterinary Medicine, Sulaimani \\ University, \\ Sulaimani, Iraq \\ nawzad1954ra@gmail.com
}

\author{
Shahnaz Abel-Kader Ali \\ College of Medicine, Sulaimani \\ University, Sulaimani, Iraq \\ shahnaz.abdulkader@gmail.com
}

\begin{abstract}
The present study was performed in Garmian area-Iraqi Kurdistan Region on doves and domestic pigeons (Columbids) which were collected during the period from the ${ }^{\text {st }}$ of December 2015 to $30^{\text {th }}$ April 2016 to study the naturally occurring of oropharyngeal parasites and their prevalence rates of infections. The wet samples were swabbed from oral cavity and pharyngeal region of all birds, and then screened by wet mount searching for parasites. The results of the current study revealed that only one species of protozoan parasite was identified which was Trichomonas gallinae. The results also showed that the total prevalence rate of infection from the total number of examined birds (249) was 54 (21.69\%). Out of the
\end{abstract} 142 doves (63 males and 79 females) and 107 domestic pigeons (62 males and 45 females) examined, 29 (20.42\%) doves [13 (20.63\%) males and $16(20.25 \%)$ females)] and $25(23.36 \%)$ domestic pigeons [15 (24.19\%) males and 10 (22.22\%) females) were infected with T. gallinae protozoon parasite. In the present study it was found that the two examined bird species were infected with this protozoon and there was a gradual rise in prevalence of infection from beginning to end of the study. Small variations in the prevalence rate of T. gallinae infection between doves (20.42\%) and domestic pigeons (23.36\%) were observed but this variation not reached to the level of statistical significance $(P>0.05)$. It is worthy to note that in all of the infected birds in the study Trichomoniasis occurred without observation of any apparent secondary diseases or signs. In conclusion Trichomoniasis is less common in urban doves and domestic pigeons in Garmian area, Kurdistan Region- Iraq. Further research is suggested in relation to protozoan parasite in other bird species in a study will be conducted in all months of the year to find the reasons which affect the prevalence rate of infection and to estimate the parasite-host relationship.

Keywords: Doves, domestic pigeons, oropharyngeal parasites, prevalence, Garmian - Iraq.

\section{INTRODUCTION}

Doves and domestic pigeons are spread everywhere on Earth, especially found around human habitations, in farmland, villages and towns, domestication of pigeons have been performed for many years that they have been employed as a diet, pets or civilized and spiritual signs [1]. In other aspects Columbids play a role as a store of Trichomonads to other bird hosts [2]. As well as transmission of many diseases are occurred by Columbiformes to humans beings and animals; many species of parasites infect Columbids, resulting in reduced performance and mortality of the host [3,4].

Trichomonas gallinae is a pathogenic Sarcomastigophoran protozoa ordinarily found in the pharynx and respiratory tracts of Columbiformes as well as in certain avian predators that feed on Columbids [5]. This parasite is the cause of Trichomoniasis in birds which is proliferative necrotic lesions known as "Canker" in pigeons. Turkeys, chickens, and a wide variety of wild birds are parasitized but with a varying degrees of pathogenicity $[6,7,8,9,10]$.

After infection with $T$. gallinae the symptoms may appear as asymptomatic or mild disease to a sudden death within 4-18 days. The clinical manifestations include regurgitation, anorexia, or respiratory failure due to large choky materials which obstruct the respiratory tract that cause death by malnutrition $[11,12,13]$.

Trichomonads do not require an intermediate host or vector and are transmitted through direct contact or through ingestion of contaminated water or food. Infected adults can transmit the parasite to their offsprings during feeding activities. Parental feeding of young is an effective method of parasite transmission. $T$. gallinae reproduces by longitudinal binary fission. Cysts, sexual stages, or vectors are not known. The organism is transferred to squabs by infection of "pigeon milk" from adults. In chicken and turkey flocks, infection is spread by contamination of drinking water 
and perhaps feed [10]. The life cycle of the parasite has no resistant stage or cyst just the trophozoite stage has been mentioned $[7,10]$.

The aims of the current study were to identify the detected oropharyngeal parasites and show the prevalence rates of infection in doves and domestic pigeons in the study area during the period extended from the $1^{\text {st }}$ of December 2015 to $30^{\text {th }}$ April 2016 and also tried to compare the prevalence rates with those reported in the previous studies and explaining the reasons of differences if they are present.

\section{MATERIALS AND METHODS}

The current study was conducted between the times which extended from $1^{\text {st }}$ of December 2015 to $30^{\text {th }}$ April 2016 in Garmian area-Iraqi Kurdistan Region, its capital is Kalar district which is located at $150 \mathrm{Km}$. Southeast of Sulaimani district center, on apparently healthy doves and domestic pigeons. Two hundred and forty nine doves (Fig. 1 A) and domestic pigeons (Fig.1 B) with different ages and genders were collected randomly from different districts, sub-districts and villages to identify the detected parasites and to study the prevalence rates of infections in both bird species. Each collected birds were directly transmitted to the parasitological laboratory, enough special feed and water are provided to them, and immediately after gentle sampling all the birds were released.

Direct smears were prepared freshly by tissue swabs from oral cavity and pharynx of each sampled from dove and domestic pigeon, was mixed gently with a drop of normal saline on a clean, dry glass slides, and covered with a cover slip, examined under the light microscope as fresh mounts $[7,14]$ to detect the flagellated parasite movement. Then to detect the internal structures of the detected parasites a drop of Logul's stain was added then covered with a cover slip $[15,16]$.

Trichomonad species were only observed by their motility and flagellates in the field of microscope (1000X) [17,18].

Comparison of overall prevalence rates of the parasitic infections between the doves and domestic pigeons as well as their sexes was analyzed by using Chi square test with employing SPSS programme. The statistical differences were distincted significant at $\mathrm{P}<0.05$. Photos were taken with iPhone 6 (s) model MKQR2AH/A, camera12- megapixel.

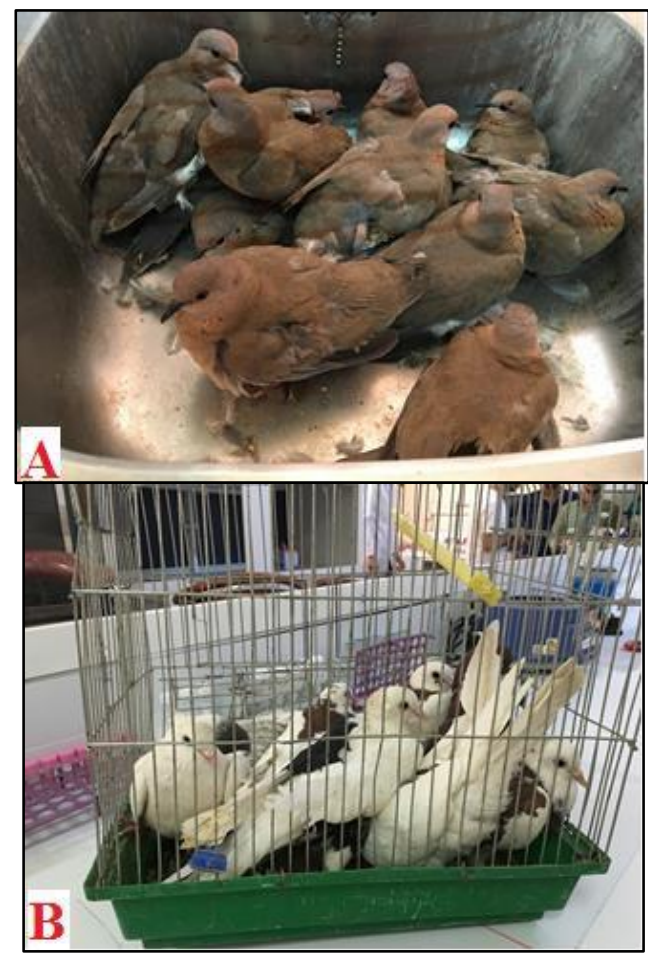

Figure (1): Pictures of doves (A) and domestic pigeons (B)

\section{RESULTS}

The only oropharyngeal parasite had been detected microscopically in this study using freshly prepared wet mount was Trichomonas gallinae protozoon Figure (2), which was observed in 54 out of 234 examined doves and domestic pigeons, thus the overall prevalence rate was $23.08 \%$, and separately, of the total of 142 doves (63 males and 79 females) and 107 domestic pigeons (62 males and 45 females) inspected in study, 29 (20.42\%) doves [13 (20.63\%) males and $16(20.25 \%)$ females)] and $25(23.36 \%)$ domestic pigeons [15 (24.19\%) males and $10(22.22 \%)$ females) were infected with this parasite Table (1). A statistical significant difference in the infection rate between the doves (20.42\%) and domestic pigeons $(23.36 \%)$ was not observed $\left(\chi^{2}=\right.$ $0.311, \mathrm{P}=0.577$ Table-1), also this difference in the prevalence rates of infections between males and females in overall examined birds was not significant $\left(\chi^{2}\right.$ $=0.075, \mathrm{P}=0.784$ Table- 1 ).

The organism was rapidly moving, pear-shaped protozoa, which have typically four free flagella arising from a basal granule at the anterior pole of the organism, a narrow prominent axostyle usually extends well beyond the posterior end of the body and an undulating membrane originates at the anterior pole of the body does not reach the posterior pole Figure (2). These morphological features of the detected $T$. gallinae were similar to those described by $[10,14,19,20,21]$. 
The infection with $T$. gallinae in birds creates lesions which is a cheese-like appearance in buccal cavity and/or esophagus, whereas these lesions were not found in this study and any signs were not showed.

Table (1): Rate of infection with Trichomonas gallinae according to sex in doves and domestic pigeons $(\mathrm{N}=234)$.

\begin{tabular}{|c|c|c|c|c|c|}
\hline \multirow{2}{*}{ Birds } & \multicolumn{2}{|c|}{$\begin{array}{l}\text { No. of } \\
\text { examined } \\
\text { birds }\end{array}$} & \multicolumn{2}{|c|}{ No.and \% of infected birds } & \multirow{2}{*}{ Rate } \\
\hline & Male & $\begin{array}{c}\text { Fem } \\
\text { ale }\end{array}$ & Male & Female & \\
\hline $\begin{array}{c}\text { Doves } \\
(142)\end{array}$ & 63 & 79 & $13(20.63 \%)$ & $\begin{array}{c}16 \\
(20.25 \%)\end{array}$ & $\begin{array}{c}29 \\
(20.42 \%) \mathbf{b}\end{array}$ \\
\hline $\begin{array}{l}\text { Domes } \\
\text { tic } \\
\text { pigeon } \\
\text { s (107) }\end{array}$ & 62 & 45 & $15(24.19 \%)$ & $\begin{array}{c}10 \\
(22.22 \%)\end{array}$ & $\begin{array}{c}25 \\
(23.36 \%) \mathbf{b}\end{array}$ \\
\hline $\begin{array}{c}\text { Total } \\
\% \\
(\mathbf{2 3 4})\end{array}$ & 125 & 124 & $28(22.4 \%)$ a & $\begin{array}{c}26 \\
(20.97 \%) a\end{array}$ & $\begin{array}{c}54 \\
(23.08 \%)\end{array}$ \\
\hline
\end{tabular}

*Values with same superscripts within a row and column were nonsignificant $(\mathrm{P}>0.05)$.

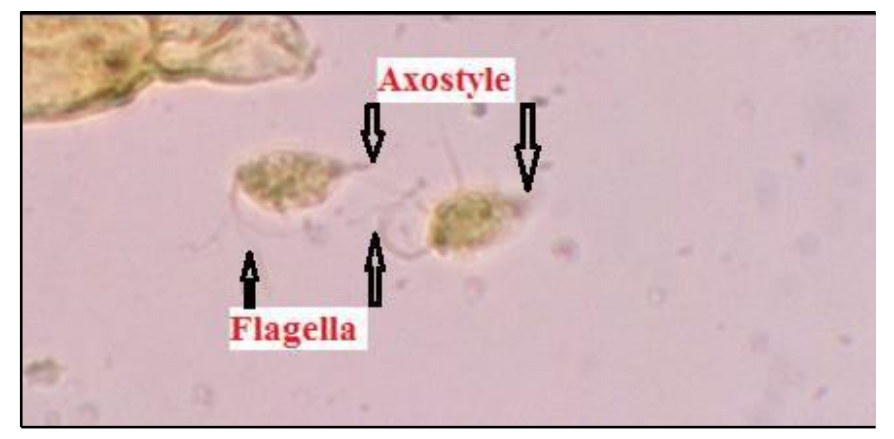

Figure (2): Trichomonas gallinae trophozoite parasite from oropharyngeal cavity of naturally infected doves and domestic pigeons stained with Lugol's stain

\section{DISCUSSION}

The current study on oropharyngeal parasites in doves and domestic pigeons in Garmian administration, Kurdistan Region-Iraq was the first one that identified the Trichomonas gallinae parasite in both examined bird species after [22] who recently reported this protozoan parasite in feral pigeons in Sulaimani province, Kurdistan Region-Iraq.

In the study, the overall prevalence of infection with $T$. gallinae trophozoite in both birds in the study area was $23.08 \%(20.42 \%$ in doves and $23.36 \%$ in domestic pigeons), statistically the differences between the rates in doves and domestic pigeons as well as their sexes were not significant. Prevalence of infection with $T$. gallinae differs in association to sex; there were no significant differences between the male and the female pigeons.

In contrast to that recently reported by [23] the present study showed that $\mathrm{T}$. gallinae in Columbids did not cause any diphtheritic lesion in oral cavity and esophagus; this was similar to the results reported by [24] who found no lesions. However, Subclinical infections with this protozoan are mainly occurred as the result of infection with apathogenic strains and host immune condition has a role to impact the progression of clinical disease [25]. The relatively high incidence of infections in otherwise normal Columbids can be attributed to strain variations, acquired immunity, or both. Pigeons are immune to disease from virulent strains of trichomonads after recovery from sublethal Trichomoniasis [26] Lesions and mortality in Columbids were found due to a pathogenic strain of the parasite [27]

The current prevalence was in line with the following studies conducted in Iraq, neighboring countries and also in other countries in the world: [28] performed a study in different species of pigeons in Mosul city, Iraq, to document Trichomoniasis during 2005-2007, three species of doves were included, stock dove (Columba oenas), rock mountain dove (Columba livia), and collared doves (Streptopelia decaocto), the prevalence rates were $22 \%, 17.50 \%$ and $10 \%$, respectively. Another study in Iraq among free-living urban pigeons from August to September 2007 was performed by [23] who reported a prevalent rate with Trichomoniasis of $16 \%$ and [29] performed a pathological study of parasitism in racing pigeons in which the rate of infection with $T$. gallinae was $26.80 \%$ in Ilam city, Iran. [30] examined 44 pigeons in Spain, Trinidad, nine harboured $T$. gallinae at a rate of $20.45 \%$. [31] investigated the rate of T. gallinae in domestic pigeon in Guangdong Province, China from July 2009 and January 2010 that was $33.90 \%$.

Whereas, the results of the current study disagreed with those recorded by most researchers. Recently three studies in Iraq were conducted about the parasite [32] reported the incidence and occurrence of Trichomoniasis in domesticated and wild pigeons at Al-Diwaniya city, the total percentages of positive results were $46 \%$, 
$30.57 \%$, for the two birds respectively. [33] found in a study of domestic and wild columbid birds in Babylon province, the infection rate with $T$. gallinae in wood pigeons was highest which was $53.33 \%$ followed by palm doves, collared doves, domestic pigeons, rock pigeons $11.12 \%, 13.34 \% \quad 30 \%, 40 \%$ and respectively. [34] found T. gallinae in domestic pigeons with obvious oral cavity lesion in Al-Diwaniya city, with the rate of $10.52 \%$. In the center of Iran, [35] performed a study on pigeons in which the total prevalence rate of $T$. gallinae was $70.09 \%$. In a study conducted by [36] recorded infection of Columba livia collected in various locations in Khorasan province, Iran, the prevalence of T. gallinae was $37.32 \%$, and in Isfahan, Iran. [36] recorded the prevalence $57 \%$ of $T$. gallinae in (Columba livia domestica) from January to June 2010. In a study monitoring the annual variation of $T$. gallinae infection for six years in doves a $5.6 \%$ of the mourning doves were seen to be positive for $T$. gallinae [38].

In Perth, Western Australia, [39] found the T. gallinae of rock Senegal doves (Streptopelia senegalensis) and racing pigeons the rates of infections were $46 \%$ and 59\% respectively.

The reasons of various prevalences of $T$. gallinae infection reported in different bird species could not be interpreted well but generally it is thought that they were related to climatic factors, geographical and seasonal variations, immunity of the birds, host ages, difference in detection assays, while seasonal variation as a obvious reason was noticed in this study as well as in previous studies [40]. Although it was proved that transmission of the $T$. gallinae can happen throughout the year, though many researchers go along with that wet seasons (spring and summer) are perfect for good outbreak [41,42]. Previous studies showed huge differences in the rate of the Trichomonads in Columbids among countries in the world $[38,39,43]$.

Prevalence rate of infection of $T$. gallinae in pigeons was higher at the warmer sites and times besides the lower rainfall [44], however these factors might support the low reported prevalence of the identified parasite in the present study which carried out in warmer regions and quite during the cold seasons of the year which were winter and spring seasons.

Host parasite relationship is much powerful so this fact was proved by the most previous studies in which authors recorded a high prevalence rate of $T$. gallinae infection and the low rate of pathological changes in Columbid birds [45].

\section{CONCLUSIONS}

The result of the present study indicated that the Trichomonad infection was quite common in doves and domestic pigeons in this area. The prevalence rates of infections with this parasite for both examined birds were almost equal and statistical differences between these rates were not significant as well as between their sexes. This study was considered the first one that conducted in this area among the Columbiformes.

\section{RECOMMENDATION}

It recommended that further investigations will be needed to survey the all bird species in this area around all seasons of the year in regards to prevalence rate of ecto and endoparasites, pathological effects of these parasites and their transmissions to other avian species, animals and humans.

For accurate and facilitation of identifying the species of the detected parasites most developmental techniques such as ELISA or PCR will be also recommended.

\section{REFERENCES}

[1] J. E. Cooper (1984). A veterinary approach to pigeons. J Small Anim. Pract., 24:505-516.

[2] R. Kumar (1998). A survey of parasitic fauna of local pigeons and assessment of efficacy of certain drugs in poultry nematodiasis. M.V. Sc. thesis submitted to C.S Azad University of Agriculture and Technology, Kanpur.

[3] D. J. Rupiper (1998). Diseases that affect race performance of homing pigeons. Part II: Bacterial, fungal and parasitic diseases. J. Avian Med. Surg., 12:81-86.

[4] C. Dranzoa, M. Ocardo, P. Katete (1999). The ecto-, gastrointestinal and haemo-parasites of live pigeons (Columba livia) in Kampala, Uganda. Avian Pathol., 28:119-124.

[5] J. A. Conti (1993). "Diseases, parasites and contaminants." In Ecology and management of the morning dove. T. S. Baskett, M. W. Sayre, R. E. Tomlinson and R. E. Mirachi (eds.). Stackpole Books, Harrisburg, Pennsylvania.PP: 205- 224.

[6] W. M. Harmon, W. A. Clark, A. C. Hawbecker and M. Stafford (1987). Trichomonas gallinae in Columbiform birds from the Galapagos Islands. J. Wildl. Dis., 23: 492-494. 
[7] E. C. Greiner and B. W. Ritchie (1994). Parasites', in: B. W. Ritchie, G. J. Harrison, and L. R. Harrison (eds.), Avian medicine: principles and application, Wingers Publishing, Inc., Lake Worth, Florida.

[8] [N. D. Levine (1995). Veterinary Protozoology. Lowa State University Press, Ames. Iowa USA, PP: 809-812.

[9] D. J. Forrester and G. W. Foster (2008) Trichomonosis, in Parasitic Diseases of Wild Birds. Wiley-Blackwell, Oxford, UK.

[10] M. Hess and L. R. McDougald (2013). "Histomoniasis (Blackhead) and Other Protozoan Diseases of the Intestinal Tract". In: D. E. Swayne, J. R. Glisson, L. R. McDougald, L. K. Nolan, D. L. Suarez and V. Nair (eds.) Diseases of Poultry. 13th edition. A John Wiley and Sons, Inc., Publication.

[11] J. R. Baker (1986). Trichomoniasis, a major cause of vomiting in budgerigars. Vet. Record, 118: 447449.

[12] E. M. Narcisi, M. Sevoian and B. M. Honigberg (1991). Pathologic changes in pigeons infected with a virulent Trichomonas gallinae strain (Eiberg). Avian D., 35: 55-61.

[13] D. L. Burton, K. A. Doblar (2004). Morbidity and mortality of urban wildlife in the Midwestern United States. Proc $4^{\text {th }}$ International Urban Wildlife Symposium. 171-181.

[14] E. J. L. Soulsby (1986). Helminths, arthropods and protozoa of domesticated animals. $7^{\text {th }}$ edition, Bailliere Tindall, London, UK.

[15] P. H. Smith, S. E. Wiles, J. B. Malone and C. M. Monahan (2007). "Collection, preservation and diagnostic methods", in: D. G. Baker (ed.), Flynn's parasites of laboratory animals. $2^{\text {nd }}$ edition, Blackwell publishing, State Avenue, Ames, Iowa, USA.

[16] A. M. Zajac and G. A. Conboy (2012). Veterinary clinical parasitology. $8^{\text {th }}$ edition. A John Wiley and Sons, Inc., Publication.

[17] A. Dovc, O. Zorman-Rojs, A. Vergles-Rataj, V. Bole-Hribovsek, U. Krapez and M. Dobeic (2004). Health status of free-living pigeons (Columba livia domestica) in the city of Ljubljana. Acta Vet. Hungarica, 52: 219-226.
[18] N. L. Anderson, R. A. Grahn, K. Van-Hoosear and R. H. Bondurant (2009). Studies of Trichomonad protozoa in free ranging songbirds: prevalence of Trichomonas gallinae in house finches (Carpodacus mexicanus) and corvids and a novel Trichomonad in mockingbirds (Mimus polyglottos). Vet. Parasitol., 161: 178-186.

[19] N. D. Levine (1985). Veterinary Protozoology. Iowa State University Press, Ames.

[20] W. J. Foreyt (2001). Veterinary Parasitology: Reference Manual. $5^{\text {th }}$ edition. Blackwell Publishing, Iowa state University Press, USA.

[21] D. G. Baker (2007). Flynn's parasites of laboratory animals. $2^{\text {nd }}$ edition, Blackwell Publishing, American College of Laboratory Animal Medicine. State Avenue, Ames, Iowa, USA.

[22] M. A. Wahhab (2015). Diagnosis of gastrointestinal tract parasites in feral pigeons (columba livia) and their effects on some serum biochemical parameters in Sulaimani province. M.V.Sc. Thesis, Coll. Vet. Med., Sulaimani Univ., Iraq.

[23] H. I. Al-Sadi and A. Z. Hamodi (2011). Prevalence and pathology of Trichomoniasis in free-living urban pigeons in the city of Mosul, Iraq. Vet. World, 4 (1): 12-14.

[24] H. Toro, C. Saucedo, C. Borie, R. E. Gough and H. Alcaino (1999). Health status of free living pigeons in the city of Santiago. Avian Pathology, 28(6): 619623.

[25] R. M. Kocan and, J. O. Knisley (1970). Challenge infestation as a means of determining the rate of disease resistant Trichomonas gallinae free birds in a population. J. Wildl. Dis. 6: 13-15.

[26] L. R. McDougald (2008). _Protozoal Infections“: Histomoniasis (Blackhead) and Other Protozoan Diseases of the Intestinal Tract, in: Y. M.Saif; A. M. Fadly; J. R. Glisson; L. K. Nolan and D. E. Swayne (eds.) Diseases of Poultry. $12^{\text {th }}$ edition, Blackwell Publishing, State Avenue, Ames, Iowa, USA.

[27] M. Marx, G. Reiner, H Willems , G. Rocha , K. Hillerich, J. F. Masello, S. L. Mayr, S. Moussa, J. C. Dunn , R. C. Thomas , S. J. Goodman , K. C. Hamer , B. Metzger , J. G. Cecere , F. Spina , S. Koschkar , L. Calderón, T.Romeike and P. Quillfeldt (2017). High prevalence of Trichomonas gallinae in wild columbids across western and 
southern Europe. Marx et al. Parasites \& Vectors, 10:242.

[28] H. S. Al-Bakry (2009). Prevalence of avian Trichomoniasis in different species of pigeons in Mosul. Iraqi J. Vet. Sci., 23 (2):105-109.

[29] A. M. Bahrami, A. L. Monfared and M. Razmjoo (2012). Pathological study of parasitism in racing pigeons: An indication of its effects on community health. African J. Biotech., 11 (59): 12364-12370.

[30] J. S. Kaminjolo, E. S. Tikasingh and G. A. A. Ferdinand (1988). Parasites of the common pigeon (Columba livia) from the environs of Port of Spain. Trinidad. Bull. Anim. Hlth. Prod. Afric., 36:194195.

[31] S. B. Qiu, C. Yan, D. H. Zhou , J. Hou, Q. Q. Wang, Y. Lin, H. C. Fu, J. Zhang, Y. B. Weng, H. Q. Song and R. Q. Lin (2012). High prevalence of Trichomonas gallinae in domestic pigeons (Columba livia domestica) in subtropical southern China. Afric. J. Microbiol. Res., 6 (13): 3261-3264.

[32] N. Sabeeh and A. AbdulAziz (2012). Isolation of birds Trichomoniasis from domesticated and wild pigeon at Al-Diwaniya city. AL-Qadisiya J. Vet. Med. Sci., 11(1): 101-104.

[33] H. M. Al-Rammahi, M. H. AL-Hasnawy and A. K. Abbas (2013). Concurrent Infection of Cestodes with Trichomoniasis in Domestic and Wild Columbides Birds in Babylon Province. The Iraqi J.Vet. Med., 37 (2): 192-198.

[34] A. A. A. Abed, H. A. Naji and A. G. Rhyaf (2014). Investigation study of some parasites infected domestic pigeon (Columba livia domestica) in AlDiwaniya city. J. Pharm. Biol. Sci., 9 (4): 13-20.

[35] Kh. Pirali-Kheirabadi, M. Shakhse-Niaie and N. Hossaini (2008). Epidemiological aspects of pigeon Trichomoniasis in center of Iran. Res. J. Parasitol., 3(1): 20-24.

[36] H. Borji, G. H. Razmi, A. H. Movassaghi, E. Moghaddas and M. Azad (2011). Prevalence and pathological lesion of Trichomonas gallinae in pigeons of Iran. J. parasitol. Dis., 35 (2): 186 (Abstract).

[37] A. Nematollahi, M. Ebrahimi, A. Ahmadi and M. Himan (2012). Prevalence of Haemoproteus columbae and Trichomonas gallinae in pigeons
(Columba domestica) in Isfahan, Iran. J. Parasitol. Dis., 36 (1):141-142.

[38] J. H. Schulz, A. J. Bermudez and J. J. Millspaugh ( $\left.\begin{array}{llll}2 & 0 & 0 & 5\end{array}\right)$. Monitoring presence and annual variation of Trichomoniasis in mourning doves. Avian Dis. 49: 387-389.

[39] T. McKeon, J. Dunsmore and S. R. Raidal (1997). Trichomonas gallinae in budgerigars and columbid birds in Perth, Western Australia. Australian Vet. J., 75 (9): 652-655 (Abstract).

[40] M. H. Saleem, M. S. Khan, A. S. Chaudry and H. A. Samad (2008). Prevalence of Trichomoniasis in domestic and wild pigeon and its effect on hematological parameters. Pakistan Vet. J., 28 (2): 89-91.

[41] C. Vogel, H. Gerlach and M. Loffler (1994). "Columbiformes", in:, B. W. Ritchie, G. J. Harrison and L. R. Harrison (eds.), Avian medicine: principles and application, Wingers Publishing Inc. Lake Worth, Florida.

[42] R.W. Gerhold, C.M. Tate, S.E. Gibbs, D. G. Mead, A. B. Allison and J. R. Fischer (2007). Necropsy findings and arbovirus surveillance in mourning doves from southeastern United States. Journal of Wildlife Diseases, 43, 129-135.

[43] J. A. Conti and D. J. Forrester (1981). Interrelationships of parasites of white-winged doves and mourning doves in Florida. Journal of Wildlife Diseases, 17: 529-536.

[44] N. Bunburg, C. G. Jones, A. G. Greenwood and D. J. Bell (2007). "Trichomonas gallinae in Mauritian Columbides: implications or an endangered endemic." J. Wildl. Dis., 43 (3): 399-407.

[45] O. Krone, R. Altenkamp and N. Kenntner (2005). Prevalence of Trichomonas gallinae in Northern Goshawk from Berlin Area of Northeastern Germany. Journal of Wildlife Diseases, 41, 304309.

\section{ACKNOWLEDGEMENTS}

Thanks a lot to Head of Animal Health Department in Kalar Technical Institute, for his excellent help in the providing of the parasitological laboratory. There was no funding support for our study before publishing, all the financial needs were provided by the authors. 